\title{
APPRENTICESHIP SKILLS DEVELOPMENT WITHIN THE INFORMAL SECTOR OF THE GHANAIAN ECONOMY: THE CASE OF SUNYANI MAGAZINE
}

\author{
Korang, V. \\ Department of Management, Faculty of Economics and Business Administration, \\ Catholic University College of Ghana, P. O. Box 363, \\ Fiapre, Sunyani, Ghana. \\ Email: vida.korang@cug.edu.gh
}

\begin{abstract}
Apprenticeship training is one of the several means of developing the skills and competencies of the workforce in every economy. The small and micro-scale engineering enterprises since their inception, have been contributing towards the development of the country. This is particularly so in the manufacturing and engineering sectors where local tools, equipment and machinery are produced and serviced. The Sunyani magazine has become an emerging informal industrial zone where technical skills development is offered to individuals across different areas of engineering. This paper examined the nature of apprenticeship skills development and the associated challenges in an informal industrial zone through a cross-sectional survey. The findings suggest that on-the-job training model without pre- or post-training exams or test characterised the training of apprentices. During the skills development process of the apprentices, the master craftsmen examine the progress of the apprentices to ensure they are progressing and to determine when apprentices have acquired the needed skills to be considered certified. Despite the benefits offered to the local economy, lack of funding for new ventures, lack of government support, tools and equipment constrain the capacity of the informal industrial zone to scale-up its training capacity with the potential of being of greater benefits to the socioeconomic development of the country.
\end{abstract}

\section{Keywords: Apprenticeship, Ghana, Informal sector, Informal skills development, Sunyani}

\section{Introduction}

The informal industrial zone known as "Sunyani magazine" serves as home to micro and small size engineering and manufacturing enterprises in the Bono region of Ghana with a long history of operation. Sunyani magazine is acknowledged to have supported informal apprenticeship skills development in the region spanning over several decades. The informal industrial zone is a cluster of informal micro and small enterprise artisans that aid in the manufacturing of small engineering, industrial and agricultural products and the servicing of vehicles that contribute to economic livelihood. Many of the enterprise owners/master craftsmen within this informal industrial zone were trained through apprenticeship (Adeya, 2008). The development of the technical capabilities of the workforce is credited as critical in fostering individual employability, which in turn, support sustainable economic growth and development. It has been established in prior literature that apprenticeship is one of the several means of enhancing the skills and competencies of the workforce (Amin et al., 2013; Cole, 2002). Many organizations across the world including Ghana invest resources in workforce training to improve service delivery. The small and micro-scale engineering enterprises are contributing towards the development of the country with a focus on the youth with or without post-basic education to 
acquire employability skills through apprenticeship (World Bank, 2009).

The importance of transferring skills and knowledge in the informal industrial zone cannot be underemphasized (Adeya, 2008). The skills development at these informal industrial zones just like other informal sector businesses, if developed and managed appropriately will lead to the creation of direct and indirect employment, thereby, reducing unemployment in the country (Peter-Cookey \& Janyam, 2017). The Government of Ghana in recognizing the contribution of the informal sector towards economic development of the nation, has made various efforts in regulating and supporting skills development within the sector (Palmer, 2009). Despite several efforts by successive governments, skills development within informal industrial zones, including Sunyani Magazine, has had little attention in terms of policy support and development programming (Palmer, 2007). Prior studies indicated that, despite the informal sector's contribution in developing skills, the processes and nature of developing skills need to be examined towards the development of a useful policy framework to support the sector (UNESCO, 2010).

In general, technical skills development and by extension apprenticeship training underpins the advancement of any economy interested in striving towards industrialisation and sustainable economic growth and development (Ayentimi et al., 2018). The entrepreneurial mindset to spawn new enterprises and create new markets boosts economic growth and national development (King \& Palmer, 2010). The development of small and micro businesses is envisaged as the backbone for job creation and employment growth, particularly in Africa where the informal sector is a dominant economic sector. In developing economies across the sub-Saharan region, the informal sector is identified as the engine of economic growth given the sector's capacity to high value addition, size and scope (Ayentimi et al., 2018; Iddrisu et al., 2014).
At the enterprise level, skills development is most often connected with large corporate enterprises because of their financial capabilities but for SMEs, the lack of resources to support skills development is of major concern and directly undermine their ability to advance employee skills development programs (Fatoki, 2011). Within the broader training and development literature, skills development can be organized via on-the-job training or off-the-job training (Adeleye et al., 2014). Arguing through the lens of training and development literature, on-thejob training is receptive and appealing to micro and small-scale enterprises which involve the interplay of social interaction, experience and feedback (Anderson et al., 2000). According to Gibbs (1998), SMEs prefer practical training activities because of the requirement for firm specific skills over generic skills. They develop their skills via feedback from customers and learning from errors solving problems and seizing opportunities. Most SMEs develop skills of their apprentices (trainees) intuitively through daily practice on the job, sharing experiences and coaching as well as mentoring (Peter-Cookey \& Janyam, 2017). Despite the increasing interest in apprenticeship within SMEs, there has been limited research around apprenticeship skills development within informal industrial zones across Ghana. Arguing through the theory of human capital, Becker (1993) suggests that education and skills training were considered an important investment in any society as it has the potential to increase productivity at the firm level as well as the entire nation. In many instances, organisations demand more than just money or new machines, but human and intellectual capital that are considered a source of innovation, creativity, and firm productivity (Nafukho, Hairston \& Brooks 2004). Therefore, education and skills training are progressively an important element of the workforce in developed and developing economies. Drawing from human capital theory, this paper addressed three key research questions as follows: 
i. What processes do apprentices go through during training to acquire skills within informal industrial zones?

ii. How does this form of apprenticeship training arrangement benefit the trainee and their master craftsmen?

iii. What are the challenges associated with the apprenticeship training model within informal industrial zones?

This paper contributes to training and development policy and practice in several ways. First, the paper highlights ways in which apprenticeship training model within informal industrial zones can be developed and supported to contribute to vocational and technical skills development in Ghana. Second, the evidence in this paper offers guidance to policymakers on the role of informal industrial zones in technical skills development and how government can address the challenges facing the sector. Finally, this paper provides a reference point for further research in the domain of informal skills development within small and micro-engineering enterprises in developing economies.

\section{Human Capital Development Framework}

According to the ILO (2003), human capital development is important to national development and support improvements in productivity, access to employment opportunities and income. Fundamentally, the driving force for social development and economic growth for any country will significantly depend on investment in skills development and human capital (ILO, 2003). This conceptual framework is grounded on human capital theory and prior literature around skills development within the informal sector of the economy (Ayentimi et al., 2018). There is evidence to support the assumption that human capital can be developed either through the formal education system or the informal training system (apprenticeship) (Donald, Baruch \& Ashleigh, 2019). Skills development within the informal sector offers several benefits linked to entrepreneurship, innovation, job creation, poverty reduction which support economic growth and development (Fluitman \& Haan, 2002). Drawing from development economics literature, there has been well-grounded evidence to suggest that investments in skills training and development are beneficial and strongly linked to positive labour market outcomes and economic growth (Du Plessis, 2006; Fluitman \& Haan, 2002).

Human capital development remains a national priority for every society and serves as an essential part of increasing employment opportunities, reducing poverty, improving a country's competitiveness, and increasing economic growth (Du Plessis, 2006). The changing dynamics of the global and national economies characterized by an increasing use of information, advancement in technological and increasing skills requirement for jobs dictate the need for improvement in the competencies and skills of the workforce. Drawing from human capital development literature, the Global Monitoring Report (2012) highlighted three different classifications of skills to be significant. These are (i) foundation skills: literacy and numeracy skills; (ii) transferable skills: skills that support individuals to adapt to different work circumstances. They include communication skills and problem-solving skills; (iii) technical and vocational skills: these are skills that prepare individuals for a specific professional task. This includes the skills taught by the craftsmen in informal industrial zones. Essentially, foundation skills are fundamental to the acquisition of the other two skills underscored. Thus, limited numeracy and literacy skills are likely to hamper the development of transferable vocational and technical skills. 


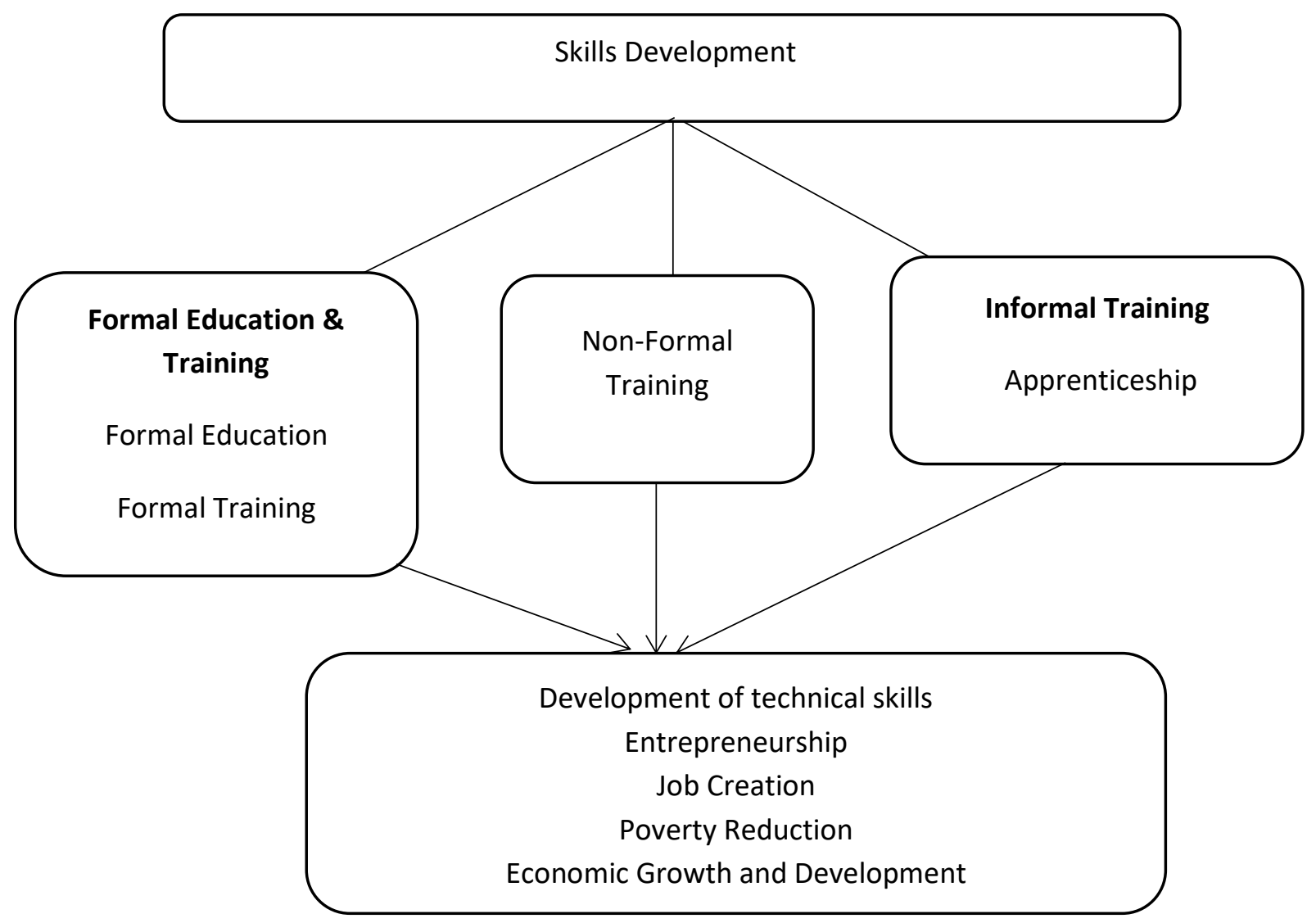

\section{Figure 1: Human Capital Development Framework}

In many developing countries, skills development emanates from formal educational training, nonformal training and informal training also known as apprenticeship. These three forms of training are capable of developing entrepreneurs thereby leading to economic growth, job creation, poverty reduction and the development of technical skills as depicted in figure 1 above. Drawing from prior empirical literature, Singh (2012) found three key skills to be particularly relevant, these include social or interpersonal skills, problem-solving skills, and technical skills. Xaba et al. (2002) report that $89 \%$ of the total labour force in Ghana can be found in the informal sector, with women representing majority of the workforce in the sector. The strategy to skills development in the formal sector is almost exclusively informal learning processes and unstructured in nature (Mathias et al., 2015). Mamgain and Awasthi (2001) revealed that investment in training activities of workers in the informal sector is practically challenging if not impossible due to several factors. The evolving literature argues that the limited training opportunities in the informal sector are primarily due to resource constraints and the risk of staff turnover which discourages employer's investment in employee skills development (Mamgain \& Awasthi, 2001). Monk et al. (2008) found that nearly $25 \%$ of apprentices make up the Ghanaian working-age with $28 \%$ of them residing in urban cities and towns. They reported further that $55 \%$ of the workforce acquired their skills via apprenticeship as against $17 \%$ of the workforce that had formal vocational training background (a formal training center or school).

Skills Development in the Informal Sector in Ghana Historically, the informal sector remains the major source of employment for the teeming youth within the sub-Saharan Africa region (UNECA, 2011). 
Indeed, the informal sector represents small-scale economic activities generally unregulated unlike the formal sector which is regulated in accordance with various government regulations. Due to the high unemployment rate in most West African countries, the informal sector mostly absorbs those who are not able to get employment in the formal sector (Ayentimi et al., 2018). These individuals range from those with formal technical and vocational education to those with informal apprenticeship skills training. According to the ILO (2011), the informal sector comprises small and micro selfemployed enterprises, or household enterprises that rely predominantly on family labour. Within the informal sector, the production processes reasonably involve high levels of working capital as against fixed capital. This situation reflects the comparatively low level of skills and technology utilization. The informal sector is construed to signify individuals engaging in either subsistence or small-scale business operations outside the legal regulations of an economy (Ayentimi et al., 2018). It is often the first training ground for young people in most developing economies across the subSaharan region. A formalized and structured vocational training system is often accessible to a few people and the rest of the population that failed to participate in a formal vocational training programme become skilled in an activity or trade with the help of master craftsmen (Walther, 2012).

In Ghana, limited jobs and the rampant exploitation of those who are lucky to be employed means that people need to earn a living as independent workers or self-employed. The informal sector in Ghana serves as an avenue for developing the skills of majority of the citizens while it also employs majority of the country's labour force. According to the Ghana Statistical Service (2012), the informal sector employs about $87 \%$ of the total workforce. Informal sector skills development activities directly help majority of the labour force to move away from subsistence activities and gradually progress towards added value activities. Data available in studies indicate the high percentage of the labour force in the informal sector acquire skills through informal, unstructured training processes (Ayentimi et al., 2018). In recent times, governments have demonstrated commitment and support for the sector through which some initiatives were put in place in 2008 to develop a regulated informal sector apprenticeship system called the National Apprenticeship Programme (NAP). The main component of the programme was to target Junior High School (JHS) graduates, particularly, those who failed to enter Senior High School. The aim of NAP was to provide this cohort of students with twelve (12) months of skills development training. As part of the training initiative, apprentices were to receive toolkits after completing the programme to enable such beneficiaries start their own small businesses. The success of this programme has not been examined to identify areas of successes and areas for improvement.

Processes involved in Skills Development in the Informal Sector

Though the workforce within the informal sector can potentially develop their technical competencies and skills via both formal and informal training approaches, they tend to benefit more from the informal or apprenticeship training arrangement. It is important and appropriate for training programmes to be designed and structured differently according to the peculiar circumstance of the sector. These may include low level of education of the workforce, the informal nature of skill development and many others. On the one hand, formal education and training is aimed at equipping individuals with generic skills, whereas vocational training centres focus on the acquisition of jobrelated or occupational skills (Easton et al., 1997). Skills development contributes to career development and impact individual occupational success. Prior literature provides evidence to suggest that the rate of return to basic education is greater because individuals who lack such basic education are more likely to end up working in unattractive trades and as family helpers (House \& Paramanathan, 2004). Birks et al. (2004) reported that the absence of basic education potentially impedes individuals from participating in formal 
education and highly skilled training later during their working life.

In general, tertiary and secondary education training programmes are generally not designed for the training of the kind of skills required by employers in the informal sector (Birks et al., 2004). Singh (2000) noted that the implementation of informal training programmes should best respond to the skills needs of the informal sector as formal training programmes are generally too theoretical in focus. Many scholars have noted that formal education training programme can be characterised by specific entry requirements, high cost of training, and the lack of flexibility which may potentially restrict the workforce with limited or no formal education to participate (House \& Paramanathan, 2004). According to Singh (2000), formal training may not be responsive to market demand within the informal sector of the economy where there is preference for practical skills over theory.

Singh (2000) argued that individuals working within the informal sector may be hesitant to participate in formal training programmes because of their lack of formal education. Therefore, non-formal training programmes take place outside the domain of formal educational system. Interestingly, non-formal education training can typically have a specific clientele with its own learning objectives. Some advantages of non-formal education include costs, accessibility, and increased participation; it can offer a tailored form of training to specific target cohorts. Non-formal training programmes facilitate young people access to formal vocational training; it also supports those already working to acquire new skills or improve existing skills (UNECA, 2011; Singh, 2000). The benefits of non-formal training include its flexibility and the ability to design targeted training programmes to correspond to the needs of communities. Non-formal education training is typically characterized by the absence of a formal curriculum and structure, and the lack of specific timelines for learning. In addition, within an informal training programme, the theoretical focus of the training is absent. Generally, the training activity can take place within the community or at the family level in the form of community-based training, mentoring and mostly on-the-job training.

Apprenticeship is commonly used in developing skills in developing countries such as Ghana. The developmental cornerstone of the informal apprenticeship model is the opportunity to provide a service or deliver a product while acquiring skills and knowledge that is essential to complete the task. The key benefit is that such kind of skills development is job specific, and without the requirement of a standardized curriculum (Walther, 2012; Overwien, 1997). It typically involves a master/apprentice relationship as part of the learning process. Informal apprenticeship allows more young people to acquire new skill set than would have been possible within a formal educational system in developing countries with limited formal educational opportunities (Palmer, 2008). It can be argued that informal apprenticeship schemes are flexible and offer self-regulating dynamic skills transmission. According to the World Bank (2015), up to $65 \%$ of the workforce in micro and small-scale enterprises have acquired their entrepreneurship skills via informal apprenticeship model. In the case of sub-Saharan Africa, it is estimated that $79 \%$ of the informal sector workforce in urban cities across the region acquired their skills through apprenticeship.

Challenges Associated with Apprenticeship skills Development in the Informal Sector

Regardless of the unlimited benefits of informal skills development, there are several related challenges that impede the sector's capacity to develop the needed human capital (Johanson \& Adams, 2004). First, the lack of an impact assessment system for skills development programmes in the informal sector persists in many developing countries. For instance, it is consistently becoming extremely challenging to put forward a case for national recognition and funding support for the sector without a system for measuring its success and impact (Ayentimi et al., 2018). Evaluating the impact of informal sector skills development unlike the formal sector is more complex as data is more 
difficult to gather, especially in developing economies where institutional systems are either non-existent or weak (UNESCO, 2010). In the informal sector, there is mostly the lack of various equipment and tools needed for the skills development training to be effective and efficient. Despite the practical nature of the skills development process in the sector, training activities are mostly conducted only when there is a request from a customer. The training is done using the tools and equipment of the master craftsmen at most times (Easton et al., 1997). Apprentices mostly experience difficulties in raising funds to support their training. As shown by Walther (2012), although it is cheaper to acquire skills within the informal sector, apprentices still experience the difficulty of raising funding to support their training. Apprentices mostly need funding for their daily upkeep, payment of master craftsmen's fees in addition to acquisition of tools and equipment. A typical apprenticeship training model is based on the ideas and skills of the master craftsmen and their willingness to pass on the knowledge and skills. On the one hand, the knowledge of the apprentice may be limited to the ability of the master craftsman to transfer skills (Marsick \& Watkins, 1990). In addition, the lack of exposure to modern technological training systems can undermine the usefulness of the training. The range of skills of master craftsmen may be narrow, constrained to a particular process; these skills may easily become outdated in the rapidly transforming work environment (Overwien, 1997).

\section{Methodology}

This study is grounded in a quantitative research design. The choice of a quantitative research design was based on two considerations. First, quantitative research design necessitates meticulous experimental design to make the research findings trustworthy. Second, the research design supports the generalization of the study findings. Following the choice of a quantitative research design, the researcher adopted a cross-sectional survey strategy (Saunders et al., 2007). A cross-sectional survey was used to investigate the research problem by selecting samples to analyze and discover occurrences within a specified time. The Sunyani municipality is home to the capital city of Bono Region and agriculture remains the key source of economic livelihood with approximately $48 \%$ of the population depending on it, while $24 \%$ of the population work in the services sector. The target population of the study was the artisans at the Sunyani magazine. This consists of apprentices and their supervisors who are affectionately called 'master craftsmen'. The choice of the target population was based on the research questions which aimed to examine the nature of skills development and the associated challenges within informal industrial zones. Sunyani Magazine represents one of the informal industrial zones in the Bono region, where informal apprenticeship training is provided to the youth. Based on prior anecdotal studies conducted, the total population of registered master craftsmen and apprentices within the Sunyani Magazine was estimated at 2309. Convenience sampling supports the selection of respondents from the target population on the basis that the respondents are easy to find for the data collection. Due to the nature of the study, the researcher used a convenient sampling procedure to gather the data. This made it possible to get the respondents who could afford some time and were willing to offer responses to the self-administered survey questionnaire. The questionnaire was designed to correspond with the research questions. The questionnaire was piloted with a sample of six respondents; the feedback was used to modify the final survey questionnaire. Two separate questionnaires were designed for the two categories of respondents (master craftsmen and apprentices). The researcher collected the data from twenty (20) master craftsmen and forty (40) apprentices. The researcher then used descriptive statistics such as graphs, tables, and charts to analyze the data. This allowed the researcher to make meaningful conclusions out of the data.

\section{Findings}

Table 1 presents the specific field of operations of the respondents. A large proportion of the respondents were into auto mechanic training, whereas the rest of the respondents were into 
Windscreen Fixing, Spraying, Electrical practicing, and Vulcanizing. The evidence suggests that the duration of the training is roughly expected to last for four years however, this depends on the judgment of the master craftsmen and to some extent the apprentices involved in the training. Thus, the ability of the individual to acquire the relevant skills during the training sometimes determines the duration of the apprenticeship training. It was also found that the master craftsmen requested for cash payments in advance as training fees in addition to other materials from apprentices before they are admitted into the apprenticeship training.

Table 1: Nature of Operations of Respondents

\begin{tabular}{llclc}
\hline Nature of Activity & Masters & & Apprentices \\
\hline Auto Mechanic & 14 & $70 \%$ & 30 & $75 \%$ \\
Sprayers & 2 & $10 \%$ & 3 & $8 \%$ \\
Electricians & 2 & $10 \%$ & 5 & $13 \%$ \\
Vulcanizing & 1 & $5 \%$ & 1 & $2 \%$ \\
Windscreen Fixers & 1 & $5 \%$ & 1 & $2 \%$ \\
\hline Total & 20 & 100 & 40 & $100 \%$ \\
\hline
\end{tabular}

Source: Field survey (2019)

The findings suggest that apprentices did not take any pre-training test or exams before starting the skills development. However, before they could start the training, the respondents indicated that they were made to bring various items needed for the kind of training or field they intend training for. A few of the apprentices also indicated that they were made to pay some money and provide drinks to their masters before they started the training process. In terms of the relevance of the training approach, the respondents were asked various questions on the training process they went through to acquire the skills needed in their field. Further, the apprentices described the training they received under their master craftsmen and the benefits they stand to gain from such training as follows. According to the apprentices, they can be self-employed after the skills training; they will gain respect in the society due to the skills they have acquired; they are able to contribute to society and support their families with money they gain from working as mechanics. Generally, the skills development process helps the apprentices to undertake meaningful ventures in their life which otherwise would not have been possible had it not been the skills acquired from their master craftsmen. With reference to their view on the training approach (figure 2), majority of the apprentices indicated that the training received under their masters was very concise, whereas $15 \%$ indicated that it is too broad. Interestingly, none of the apprentices described the training they received as either limited or not relevant.

\section{Figure 2: Views on Training Approach}

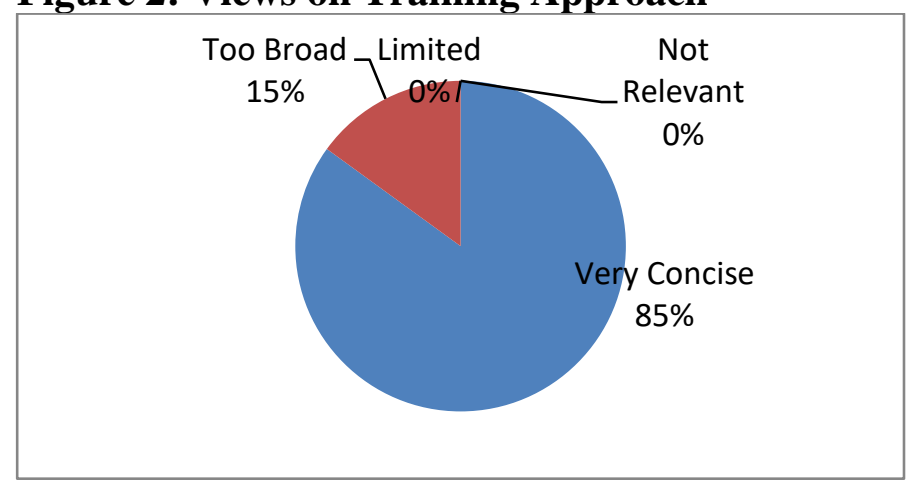

Source: Field survey (2019)

The Mode of Training Apprentices in Informal Industrial Zones (Sunyani Magazine)

With regards to the mode of training used by the master craftsmen during the training process, the findings indicated that all the master craftsmen applied on-the-job training model. In describing the processes involved in the training of the apprentices, the master craftsmen indicated they observe the progress of the apprentices during the training 
process. The apprentices start running errands when they are first admitted. They are later made to observe the processes involved in the activities of the craft they intend to be trained in. After some period, the apprentices are made to work on small machines, and this helps them to learn the use of various tools and equipment that are linked to the activities. They are later made to work on some machines and in some cases, cars and trucks under supervision from the master craftsmen. Based on the judgement of the master craftsmen, apprentices will then be allowed to work on cars and machines without direct supervision. This is mostly the stage where apprentices are considered to have acquired the relevant skills to be considered certified.

During the skills training, the master craftsmen examine the progress of the apprentices to ensure they are progressing as planned. The figure below shows the responses of the master craftsmen as to how they examine apprentices skills training progression.

Figure 3: Methods of Examining the Skills Development Process of Apprentices

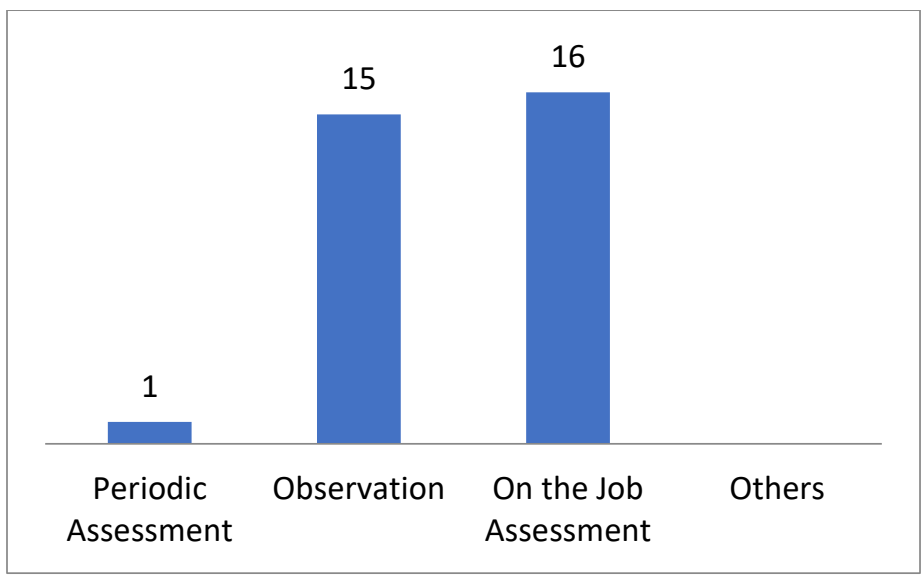

Source: Field survey (2019)

The master craftsmen mostly used observations and on the job assessments in examining the progress of the apprentices. These methods are used to determine the areas that need to be improved by the apprentice and those areas that the apprentice needs to make adjustment. The master craftsmen indicated that after the apprentices are certified, some stay with their master craftsmen as employees and others engage in self-employment by setting up their own workshops. However, majority of the master craftsmen indicated that, they do not have a plan in place to ensure apprentices get employed or are able to start up their own work. The master craftsmen indicated they also learn a lot from the apprentices and receive additional skills training from other colleagues.

\section{Benefits of Informal Apprenticeship Training model} The master craftsmen indicated that they achieve various benefits from nurturing the skills of others including money through the fees paid by apprentices. The master craftsmen suggested they continuously improve upon their skills via the mentoring, coaching and advise offered to apprentices. They also derive intrinsic satisfaction as the apprenticeship skills they offer to the youth lead to the creation of employment, reduction in crime rate among the youth, generation of revenue and the reduction in family dependence. Overall, they feel proud as master craftsmen because their work contributes tremendously towards the development of the region and the country.

Table 2: Benefits of Skills Development to the Master

\begin{tabular}{|c|c|c|}
\hline Benefits & Frequency & Percentage \\
\hline Increase in Skills & 12 & $60 \%$ \\
\hline $\begin{array}{l}\text { Sharpen already } \\
\text { gained skills }\end{array}$ & 13 & $65 \%$ \\
\hline Gain new skills & 4 & $20 \%$ \\
\hline Gain new employees & 1 & $5 \%$ \\
\hline $\begin{array}{l}\text { Contribute to the } \\
\text { Socio-economic } \\
\text { development }\end{array}$ & 17 & $85 \%$ \\
\hline
\end{tabular}

Source: Field survey (2019)

\section{Challenges Associated with Apprenticeship Training in Informal Industrial Zones (Sunyani Magazine)}

The findings suggest that master craftsmen faced several challenges which undermine apprenticeship 
training in informal industrial zones. The respondents highlighted the lack of tools and equipment, lack of funding for apprentices, the shabby nature of some apprentices, the lack of funding to start new ventures after training and the lack of support from the government

Table 3: Challenges highlighted by Master Craftsmen

\begin{tabular}{lcc}
\hline \multicolumn{1}{c}{ Challenge } & Frequency & Percentage \\
\hline During Skills Development & & $38 \%$ \\
Lack of Tools \& Equipment & 15 & $48 \%$ \\
Lack of Funding for Apprentices & 19 & $20 \%$ \\
Lack of Exposure to modern technology & 8 & $18 \%$ \\
Gender biased & 7 & $13 \%$ \\
Others & 5 & $15 \%$ \\
After Skills Development & 6 & $33 \%$ \\
Lack of Employment & 13 & $43 \%$ \\
Lack of funding for new ventures & 17 & $15 \%$ \\
Lack of support from the government & 6 & $10 \%$ \\
Lack of tools and equipment & 4 & \\
\hline Lack of assessment scheme & & \\
\hline
\end{tabular}

Source: Field survey (2019)

On the part of the apprentices, it was observed that challenges, such as lack of funds, tools and equipment, were significant challenges they faced. In recommending various ways through which apprenticeship training within informal industrial zones could be enhanced, the respondents indicated that there should be support from the government and other private agencies. In all, there was convergence in the challenges affecting both apprentices and their master craftsmen.

Table 4: Challenges highlighted by Apprentices

\begin{tabular}{lcc}
\hline \multicolumn{1}{c}{ Challenges } & Frequency & Percentage \\
\hline Lack of Funds & 28 & $70 \%$ \\
Lack of Commitment from Master & 6 & $15 \%$ \\
Poor Interpersonal Relationship with Masters & 7 & $18 \%$ \\
Lack of Tools and Equipment & 26 & $65 \%$ \\
Lack of a guide to training process & 4 & $10 \%$ \\
Lack of support from family & 2 & $5 \%$ \\
\hline
\end{tabular}

Source: Field survey (2019)

\section{Discussion}

The study examined the nature of apprenticeship training and the associated challenges within an informal industrial zone - Sunyani magazine. The master craftsmen used observation to determine the progress of apprentices and the duration of the training programme. While apprenticeship training is mostly three to four years, other factors can influence the duration. These include the capacity and seriousness of the individual being trained. There were no entry requirements for apprentices before they could partake in the training though most of them have basic education. On-the-job training 
remains the preferred training model where the master craftsmen observed the progress of the apprentices. Overwien (1997) presented that during the training process, the master craftsmen used observation and on the job assessment to examine the progress of the apprentices.

Generally, skills development helps the apprentice to be able to undertake meaningful ventures through self-employment (Palmer, 2006). The benefits highlighted by the master craftsmen include the opportunity to increase their skills, sharpen their skills and an opportunity to contribute to national development. Fluitman and Haan (2002) asserted that skills development increases quality, productivity, diversity as well as safety and health. Through this, the income of both the individual and the organization is increased hence reduce poverty. Skills development helps in the reduction of the unemployment rate within a country. Through skills development, the apprentices develop various business skills and experience which is crucial to the future survival of the individual as an entrepreneur. In Ghana, most individuals who go through various skills development programmes tend to start their own business thereby reducing the teeming and ever-growing unemployment rate within the country (Ayentimi et al., 2018). Traditional apprenticeship training which is the common form of skills development represents the most comprehensive training opportunities for the poor and it is also an important source of technical skills for those who cannot access formal training (Palmer, 2006). Most often, apprentices start their own business after the training has been completed. Unlike formal education systems, apprentices who complete their skill development process rarely remain unemployed. On the one hand, the relationship between apprenticeship skills development and selfemployment is not automatic; apprenticeship skills development outcomes are defined by several factors such as quality of training and state of the entrepreneurial ecosystem in the country, and level of government support (King \& Palmer, 2006). The master craftsmen and apprentices encounter challenges including the lack of tools and equipment, lack of funding, attitudes of some apprentices, apprentices lack of funds to start new ventures, and lack of support from the government towards informal skill development in informal industrial zones. Walther's (2012) research findings on informal sector skills development highlighted similar challenges.

\section{Towards improving Informal Apprenticeship Skills Development in Ghana}

The measures to support and develop the informal sector skills development agenda must start from identifying the weaknesses within the sector. First, the current informal apprenticeship model limits learning to the experience and knowledge of the 'master'. It is characterised by trial and error learning and learning by imitation and could be improved by adding some formal instructional designs to allow for the integration with elements of theoretical knowledge. This approach is to reduce the level of divergence between an excessive academic focus and a practical centred training (Easton et al., 1997).

Second, informal sector skills development can also be improved by combining theoretical learning and technical learning on-the-job. Overwien (1997) argues that, to ensure the significance of skills development, training should not be delivered in seclusion from the labour market needs and the opportunities associated with each region's unique economic conditions. The training should be a combination of technical and management skills. This will enable the apprentices to use the skills developed through the training programme to start up or set up their own businesses in case they are not able to gain employment. To acquire a wide range of competencies and skills, apprentices could occasionally swap roles within a pool of small enterprises. This will require close partnership with a training center for success in such arrangements. It will also enable the apprentices to be conversant with an array of technical skills and not limited to the knowledge of his or her master alone. 
Third, regulating and supporting the informal sector will enhance the skill development of the sector. This will put an end to the exploitation and other negative issues that come along with informal sector skill development. It has been argued that the approach to skills development in the informal sector in Ghana aligns with a top-down approach, which contributes to its lack of labour market relevance (Palmer, 2007). Therefore, Ghana needs a renewed approach that recognizes the multitude of available opportunities to train the youth. The government and other stakeholders need to put in measures to support the sector. This will help to support skills development in the informal sector to enhance economic development.

\section{Conclusion}

The informal sector plays a substantial role in the socio-economic development of Ghana in several ways. Informal industrial zones being part of the informal sector are contributing to skills development and offering several benefits to master craftsmen, apprentices and the municipality. It has helped create employment opportunities, reduced crime rate among the youth, and generated revenue for the municipal assembly. In terms of social benefits, it has helped apprentices gain respect from family members and society. The master craftsmen were inherently proud of their contribution to the development of Ghana. The challenges undermining the effectiveness of skills development within informal industrial zones included lack of funding for new ventures, the lack of government support and the lack of tools and equipment.

\section{References}

Adeleye, A. D., Adegbite, S. A., \& Aderemi, H. O. (2014). Training and manpower development in public research and development organizations. International Journal of Academic Research in Management, pp. 257-275.

Adeya, C. N. (2008). Knowledge, technology, and cluster-based growth: Africa. World Bank.
Anderson, V., Boocock, G., \& Graham, S. (2000). An investigation into the learning needs of managers in internationalizing small and medium-sized enterprises. Journal of Small Business and Enterprise Development, 8, 215-232.

Ayentimi, D. T., Burgess, J., \& Dayaram, K. (2018). Skilled labour shortage: a qualitative study of Ghana's training and apprenticeship system. Human Resource Development International, 21 (5), 406-424.

Becker, G. S. (1993). 'Nobel lecture: the economic way of looking at behavior'. Journal of Political Economy, 101, 385 - 409.

Birks, S., Fluitman, F., Oudin, X. \& Sinclair, C. (2004). Skills acquisition in microenterprises

Evidence from West Africa. Development Centre Documents. Organisation for Economic Cooperation and Development, ILO/World Bank.

Cole, G. A. (2002). Personnel and Human Resource Management. United States: Thomson Learning.

Donald, W., E., Baruch, Y., \& Ashleigh, M. (2019). The undergraduate self-perception of employability: human capital, careers advice, and career ownership. Studies in Higher Education, 44(4), 599-614.

Du Plessis, J. V. (2006). A Practical Guide to Labour Law. Durban: LexisNexis Butterworths.

Easton, H., Gushee, K., \& Liebert, D. (1997). Informal educational strategies for skill acquisition in West Africa: A Review of the literature and of recent significant research results. Association for the Development of Education in Africa Working Group on NonFormal Education, Florida: Florida State.

Fatoki, O. O. (2011). The Impact of human, social and financial capital on the performance of Small and Medium-Sized Enterprises (SMEs) in South Africa. Journal of Social Science, $\quad 29, \quad 193-204$. doi.org/10.1080/09718923.2011.11892970 
Fluitman, F., \& Haan, H. (2002). Informal sector training, in World Bank study on Vocational.

Edinburgh: ILO/SIDA.

Ghana Statistical Service (2012). The 2010 population and housing census: Summary report of final results. Accra: Sakoa Press Limited.

Gibb, A. A. (1998). Small firms training and competitiveness. building upon the small business as a learning organization. International Small Business Journal, 15, 13-29.

Gibbs, M., Leveson, A., \& Zoghi, C. (1995). Incentive compensation in a corporate hierarchy.

Journal of Accounting and Economics, 19(2-3): 247-277.

House, W. J., \& Paramanathan, K. (2004). Promotion and training issues in the informal sector in the context of rapid population change. UNFPA Country Support Team, South Pacific: UNFPA.

Iddrisu, S., Alhassan, E., \& Kinder, T. (2014). Polytechnic education in Ghana: management delivery and challenges. The International Journal of Social Sciences and Humanities Invention, 1(6), 2349-2031.

ILO. (2003). Working out of poverty. International Labor Organization.

ILO (2011). Upgrading informal apprenticeship systems. ILO.

Johanson, R. K., \& Adams, A. V. (2004). Skills Development in Sub-Saharan Africa. Regional and Sectoral Studies. Washington, DC: World Bank. (c) World Bank. https://openknowledge.worldbank.org/handl e/10986/15028 License: CC BY 3.0 IGO.

King, K., \& Palmer, R. (2010). Planning of technical and vocational skills development. Fundamentals of Educational Planning series. UNESCO.

King, K., \& Palmer, R. (2006). Skills, capacities and knowledge in the Least Developed Countries: new challenges for development cooperation. Background paper for the 2006
UNCTAD Least Developed Countries Report, Edinburgh: CAS.

Mamgain, R. P., \& Awasthi, I. C. (2001). Technology and training for informal sector: Need of new initiatives. New Delhi: Manohar Publishers.

Mathias, P., Gengaiah, U., \& Venkatram, R. (2015). Skills Development in the Informal Sector in India: The Case of Street Vendors. International Review of Education, 61(2), pp. 190-209.

Mauro, H. A., Gerard, E., \& Parodi, E. (2009). Learning in an urban environment. Training in the informal sector in Africa. Country analysis: Country analysis of Mali, Senegal, Benin and Mauritania. Geneva: ILO.

Monk, C., Sandefur, J., \& Teal, F. (2008). Does Doing and Apprenticeship Pay Off? Evidence from Ghana. Working Paper 200808. CSAE Working Paper Series. Oxford: Centre for the Study of African Economies, University of Oxford

Nafukho, F., M., Hairston, N., \& Brooks, K. (2004). Human capital theory: implications for human resource development. Human Resource Development International, 7(4), 545-551.

Overwien, B. (1997). Employment-oriented nonformal training for young people in the informal sector in Latin America. Journal of Education Review, 55(3), 57-83.

Palmer, R. (2006). The social composition of skill acquisition and its labour market outcomes in

Ghana: report of the southern fieldwork, Improving the Outcomes of Education for Pro-Poor Development. Edinburgh: CAS.

Palmer, R. (2007). Skills for work? From skills development to decent livelihoods in Ghana's rural informal economy. International Journal of Educational Development, 27(4), 397-420.

Palmer, R. (2009). Formalizing the Informal: Ghana's National Apprenticeship Programme. 
Journal of Vocational Education and Training, 61(1), pp. 67-93.

Peter-Cookey, M. A., \& Janyam, K. (2017). Reaping just what is sown: Low-skills and lowproductivity of informal economy workers and the skill acquisition process in developing countries. International Journal of Educational Development, 56, 11-27.

Saunders, M., Lewis, P., \& Thornhill, A. (2007). Research Methods for Business Students. Pearson Education.

Singh, M. (2000). Combining work and learning in the informal economy: implications for education, training and skills development. International Review of Education, 6(6), 599-620.

Singh M. (2012). India's National Skills Development Policy and Implications for TVET and Lifelong Learning. In: Pilz M. (eds) The Future of Vocational Education and Training in a Changing World. VS Verlag für Sozialwissenschaften, Wiesbaden. https://doi.org/10.1007/978-3531-18757-0_12

UNECA (2011). Strategies to Promote Youth SelfEmployment in West Africa. Addis Ababa:

UNECA.

UNESCO (2010). UNESCO Institute for Lifelong Learning, Global Report on Adult Education. UNESCO.

Walther, R. (2012). Building Skills in the Informal Sector, Background paper prepared for the

Education for All Global Monitoring Report 2012. [Online] Available at: http://www.unesco.org/new/fileadmin/MUL TIMEDIA/HQ/ED/pdf/gmr2012-ED-EFAMRT-PI-08.pdf (access on the 23 March, 2019)

Walther, R., \& Tamoifo, M. (2008). The career path of the young African, The results of a survey of young African leaders on post-primary vocational training schemes. AFD.

Weimer, J. (1995). Research Techniques in Human Engineering. [Online] Available at: https://www.maximumadvantage.com [Accessed 18 November 2018].

Wells, J. (2001). Construction and Capital Formation in Less Developed Economies Unravelling

the Informal Sector in an African City. Construction Management and Economics, 19(3), pp. 267274.

World Bank (2009). Project Information Document Concept Stage: Ghana Skills and Technology Development Project. World Bank.

World Bank (2015). Ghana - Vocational Skills and Informal Sector Support Project (English). Washington, D.C.: World Bank Group. http://documents.worldbank.org/curated/en/ 495991468032076595/Ghana-VocationalSkills-and-Informal-Sector-Support-Project

Xaba, J., Horn, P., \& Motala, S. (2002). The informal sector in Sub-Saharan Africa. Working Paper on the Informal Economy, Geneva: ILO. 